\title{
THE RELATIONSHIP BETWEEN WORK MOTIVATION, JOB SATISFACTION, AND EMPLOYEE PERFORMANCE: THE MODERATING ROLE OF PSYCHOLOGY CAPITAL AND THE MEDIATING ROLE OF ORGANIZATIONAL COMMITMENT
}

\author{
Windu Astuti ${ }^{*}$, Lia amalia ${ }^{1}$ \\ 'Economics and Business Faculty, Universitas Esa Unggul \\ Address: ' Jalan Arjuna Utara No.9, Kebon Jeruk, West Jakarta, Indonesia 11510 \\ *E-mail: windua2003@gmail.com
}

\begin{abstract}
This study aims to determine the effect of work motivation, organizational commitment, and job satisfaction on employee performance. The effect of organizational commitment mediates the relationship between work motivation on employee performance and job satisfaction on employee performance and psychological capital, which moderates the relationship between job satisfaction and employee performance. The object of this research is the employees of the state civil apparatus. They work in government agencies in the education sector of the Directorate of Senior High Schools in Jakarta. This study uses a quantitative approach with one hundred and ten respondents, sampling using a saturated sample technique, and a questionnaire as a measuring tool. Data analysis used the Structural Equation Modeling (SEM) method to test the model's suitability in this study with the help of the SmartPLS version 3 application. The results of this study conclude that work motivation, organizational commitment, and job satisfaction affect employee performance, organizational commitment can mediate the relationship between job satisfaction and employee performance but cannot mediate the relationship between work motivation and employee performance, and psychological capital can moderate the relationship between job satisfaction with employee performance.
\end{abstract}

Keywords: Work motivation, organizational commitment, job satisfaction, employee performance, and psychological capital.

JEL Classification: G3, J5, M12

Article History:

Received: April 2, 2021; Revised: August 3, 2021; Accepted: August 9, 2021; Available Online : August 28, 2021 DOI: $10.20473 /$ imtt.v14i2.26192

\section{INTRODUCTION}

The current pandemic has disturbed a person's psychological condition and affects the crisis, uncertainty, and loss of control, resulting in stress. An employee who has a psychological condition can certainly interfere with his performance. Avey et al. (2011) explained that ethics, behavior, and employee performance are influenced by the psychological capital owned by each individual. A good condition of psychological capital can suppress feelings of anxiety and stress in employees to increase work motivation. Psychological capital is closely related to the mood a person feels. Psychologically, an employee is aware and willing to contribute to building and advancing the company where he works (Amalia, 2018). So that in carrying out their duties, an employee will need adequate psychological capital so that they can do their job optimally to produce maximum performance (Santos et al., 2018). 
Excellent service quality will be realized from employee loyalty to the company based on employee satisfaction that arises from the employee management system through conducive working conditions, good communication, and the welfare felt by employees (Noah and Steve, 2018). The degree of fulfillment of an employee's duties is an employee's work performance, where an employee can be declared satisfied with his job if he already has good feelings from doing his job (Saari and Judge, 2004). Low employee satisfaction can impact low performance and can affect discipline, and result in high turnover. In contrast, high employee job satisfaction can positively impact their performance, behavior, and organization (Kalkavan and Katrinli, 2014). The foundation of employee performance is strongly influenced by the contribution of all employees, by consciously doing their work to help the organization achieve its goals which are described in individual behavior according to the workload responsibilities of each individual (Rahman et al., 2013). The organization has carried out various policies to overcome pandemic conditions to achieve organizational goals, one of which is by implementing a work schedule of $25 \%$ work from the office and $75 \%$ work from home and the creation and development of various applications as tools to support employment. Some researchers focus on organizational commitment variables, work motivation on employee performance variables, and mediator organizational commitment variables between work motivation and employee performance Suartina and Sadiartha (2019).

Similarly, research conducted by Inuwa (2016) explains that employee job satisfaction affects the performance produced by employees. There is limited research related to psychological capital, which influences employee performance and job satisfaction (Nafei, 2015). Therefore, this study intends to exploit the influence of job satisfaction, organizational commitment, and work motivation on employee performance mediated by organizational commitment and moderated by psychological capital. The purpose of this study was to see the extent to which (1) the influence of the relationship between work motivation variables on employee performance variables, (2) the influence of organizational commitment variables on performance variables, (3) the influence of job satisfaction variables on performance variables employees, (4) the influence of work motivation variables on employee performance variables is mediated by organizational commitment variables, (5) the influence of organizational commitment variables as a mediating variable on the relationship between job satisfaction variables and employee performance following the suggestions of previous research conducted by Rahim and Jam'an (2018), and (6) the influence of Psychological Capital that moderates the relationship between job satisfaction and employee performance (Nafei, 2015). 
Windu Astuti

Lia amalia

\section{LITERATURE REVIEW AND HYPOTHESES}

\section{The Relationship between Work Motivation and Employee Performance Variables}

One of the supporters in improving employee performance is the employee's motivation. Work motivation lies between the needs, encouragement, and goals it does to achieve good employee performance (Stoyanov, 2017). Although work motivation has been widely used as a variable in measuring employee performance, the results are varied. That is possible because the object of research and research locations are different. Suharto et al. (2019) explained that the formation of employee work motivation when experiencing the conditions and situations they face. Performance is the extent to which an employee contributes to the goals of the work unit and their competence due to their behavior and the application of skills, abilities, and knowledge (Rahim and Jam'an, 2018). Luthans (2015) argues that performance is defined as a result of quantity or quality, a form of results/services provided by someone. According to Pradhan and Jena (2017), performance is a multicomponent concept of a person at a fundamental level distinguished through the work process, which includes the involvement of one's behavior. Employee performance refers to behaviors, actions, and outcomes accessible to workers that contribute to organizational goals (Viswesvaran and Ones, (2000).

Research from Suartina and Sadiartha (2019) explains that work motivation variables positively influence employee performance. This finding is in line with Loan (2020), which states that the work motivation variable also has a positive impact on employee performance, which means that the higher the level of work motivation of an employee, the positive impact on the employee's performance. It can be interpreted that work motivation has a significant and positive effect on increasing employee performance variables. However, these studies contradict Rahim and Jam'an (2018), which shows that the work motivation variable does not significantly influence employee performance. Leaders are expected to be able to pay more attention, guidance, and welfare to their employees. From the literature mentioned above, the first hypothesis proposed is:

\section{$\mathrm{H}_{1}$ : Work motivation have influences employee performance variables}

The Relationship between Variable Organizational Commitment and Employee Performance Variables

With this pandemic condition, it is expected that all employees of the High School Directorate will still have a high organizational commitment to carry out their obligations following the job descriptions that have been given. According to Luthan's explanation, organizational commitment is a reflection of the loyal attitude of an employee in an organizational body through a continuous process, where it encourages the tendency of organizational members to have a caring attitude towards the success and progress of their 
organization (Fauzi et al., 2016). This commitment can be characterized by three factors: the belief in a strong goal; the totality to strive as a member of the organization; and the determination to maintain the membership system (Hashish, 2015). Jatmiko (2015) explains that organizational commitment is a global picture of an organization that is not only seen from a solid point of view on job satisfaction. An employee will try to maintain his membership in an organization and side with that organization as a form of organizational commitment that employees have (Darman, 2015). Based on Robbins and Judge (2014), an employee's sense of alignment with organizational goals and a desire to survive as part of the organization is known as organizational commitment. Organizational commitment has three components, namely: an affective commitment that occurs when employees want to maintain their membership in the organization; sustainability commitment that arises when employees try to stay in the organization, because they need wages and other benefits, or because employees do not get other jobs; as well as normative commitment that arises from within employees with the awareness to remain a member of the organization (Jabri and Ghazzawi, 2019).

Other studies show that the variable organizational commitment is used as a parameter in seeing essential behaviors such as employee performance, discipline, and turnover. The influence of the organizational commitment variable on employee performance has been proven by Jaman et al. (2018), which explains that the organizational commitment variable influences the performance improvement variable. That means that the better the organizational commitment variable will impact the tougher performance of the employees. Likewise, the research results of (2014) stated that affective commitment, commitment sustainability variables, and normative commitment variables could positively influence employee performance. Research from Rahim and Jam'an (2018) also states that organizational commitment affects employee performance variables, this is in line with (Loan, 2020) which shows that organizational commitment has a positive influence on employee performance variables, this means the higher the level of commitment, it can improve employee performance. Refer to the description above, the following hypothesis is proposed:

\section{$\mathrm{H}_{2}$ : The organizational commitment variable influences the employee performance variable.}

\section{The Relationship between Job Satisfaction Variables and Employee Performance Variables.}

In essence, an employee will make an immense contribution when he feels comfortable with his current job. Job satisfaction is one of the main factors that is believed to influence the ups and downs of employee motivation and morale at work, which can decrease employee performance (Loan, 2020). An employee can feel satisfied at work if he has achieved the target he wants (Lee et al.,2017). Job satisfaction is the employee's perception of the good 
and bad results of their work for the company (Luthans 2015). Job satisfaction is an important attitude of employees that is often studied in organizational behavior. Employees are the primary resource that runs the operational wheels of an organization (Muda et al., 2014). Inuwa (2016) further explains that employee job satisfaction has an impact on employee performance. This gives a signal that employee satisfaction tends to have a good level of performance. Job satisfaction is a complex and multidimensional thing. This can be seen in various ways by different individuals, and job satisfaction is usually very closely related to motivation even though the scope of the connection is still unclear (Aziri, 2011).

Performance is evidence of individual success, and employee performance is a multidimensional structure (Sadiq and Mohsin (2019). An employee can be declared satisfied with his job if he already has a collection of good feelings from doing his job (Saari and Judge, 2004). According to research, Balasundaram and Nimalathasan (2011) states that job satisfaction variables have a positive effect on employee performance variables, and job satisfaction variables have a significant positive effect on employee performance (Sadia and Mohsin, (2019). Platis et al., (2015). also argue that job satisfaction variables positively affect performance variables, and the most important parameter of job satisfaction in employees is from the leadership. The research results of Abdirahman et al. (2020) and (Ismail et al., 2016) prove that job satisfaction variables are related to performance variables. Based on this, it can be developed into the following hypothesis:

\section{$\mathrm{H}_{3}$ : Job satisfaction variables affect employee performance variables}

\section{The Relationship between Work Motivation Variables on Employee Performance Variables Mediated by the Organizational Commitment Variable}

Referring to the three need theories initiated by Mcclelland and Boyatzis (2016), humans have three other needs, namely the need for achievement, affiliation, and power. The need for achievement is the desire to try to achieve something much better. The need for affiliation is the desire to be liked, to build and maintain friendships. The need for power is the desire to have power/become a leader. Motivation is one of the trigger factors for employees to work hard, be loyal, and be enthusiastic in generating high productivity (Heiidjraachman et al., 2015).

A person's work motivation can increase if an employee is highly committed to producing a good performance. This is stated in Suartina and Sadiartha's (2019) research that motivation has a significant positive effect on improving employee performance, and organizational commitment can be a mediation between the two. According to Rahim and Jam'an (2018) research, work motivation affects employee performance mediated by organizational commitment. These results indicate sufficient evidence that the variable organizational 
commitment can mediate the relationship between employee work motivation and employee performance. Rahim and Jam'an (2018) found that predictions of organizational commitment include age, participation in decision making, and job satisfaction. This means that the organizational commitment variable can perfectly mediate the relationship between work motivation and employee performance variables. Based on the previous, the fourth hypothesis that can be proposed is:

$\mathrm{H}_{4}$ : Organizational commitment mediates the relationship between work motivation variables and employee performance variables.

The Relationship of Job Satisfaction Variables to Employee Performance Variables Mediated by the Organizational Commitment Variable

Several studies related to job satisfaction have been carried out, including the variable job satisfaction, which positively affects organizational commitment variables (Ismail et al., 2016). Organizational commitment also has a relationship with employee performance. Employees who are satisfied with their work and highly committed to their organization will produce high performance. The organizational commitment variable is helpful as a crucial behavioral measure, as Wagiman and Sutanto (2019) stated, which proves that organizational commitment is influenced by job satisfaction and employee performance. Organizations need to increase employee commitment to increase their job satisfaction and work performance (Loan, 2020). Job satisfaction affects organizational commitment, according to Meria and Amalia (2018). So it is assumed that to increase job satisfaction and employee performance variables, the implication is to increase organizational commitment. From the things as above, the fifth hypothesis can be developed as follows:

$\mathrm{H}_{5}$ : Variable organizational commitment can mediate the relationship between job satisfaction variables and employee performance variables

The Relationship between Job Satisfaction Variables and Employee Performance Variables as Moderated by Psychological Capital

Psychology is an important asset that both leaders and subordinates need to increase work commitment and organizational performance (Hsu et al., (2019). Psychological capital is considered a person's psychological state, is temporary, and this situation can be changed and developed in a person at any time during his life (Setar et al., 2015). According to Seligman and Csikszentmihalyi (2010), psychological capital adheres to the basic premise of positive psychology, which seeks to encourage and develop positive qualities in individuals. Psychological capital has a basic premise of positive psychology which also seeks to encourage developing positive qualities in a person (Setar et al., 2015). According to Luthans et al. (2007), the psychological development of an employee is influenced by selfconfidence in solving work challenges, optimism, and persistence in achieving goals always 


\section{Windu Astuti Lia amalia}

has positive expectations. It has strong resilience when experiencing problems to achieve success. The research results by Avey et al. (2011) found that employee performance had a positive relationship to psychological capital. Psychological capital has a sizeable positive effect on the results desired by organizations. Over time psychological capital can change employees who show an increase/decrease in psychological capital will also show an increase/decrease in their performance (Luthans et al., 2010).

Job satisfaction is a feeling of satisfaction that a person feels at work as a form of a combination of the psychological environment and the physiological conditions he experiences (Abdirahman et al., 2020). Furthermore, it is explained that a person will feel the job satisfaction he gets with a different level of feeling. With the fulfillment of job satisfaction, employees can work comfortably (Noah and Steve, 2018).

A study conducted by Nafei (2015) proves that psychological capital can influence employee performance by developing self-efficiency, optimism, hope, and resilience/resilience in employees. Psychological capital is the most influential way to achieve employee performance (Rabenu s., 2017 and Santos et al., 2018). Luthans and Avelio (2017) conducted a study to analyze how four dimensions in psychological capital, namely hope, resilience, optimism, and efficacy individually and as a higher composite structure factor, predict job performance and satisfaction. The results of this study indicate that the composite factor can be a better predictor of performance and satisfaction. Employees who are more hopeful, optimistic, effective, and resilient may be more likely to overcome problems from the type of dynamic global environmental context that most organizations face today the better if it is supported by psychological capital. From the discussion above, the final hypothesis is proposed:

\section{$\mathrm{H}_{6}$ : Psychological capital moderates the relationship between job satisfaction and employee performance.}




\section{RESEARCH METHODS}

Based on the above hypothesis, we draw the research model as follows:

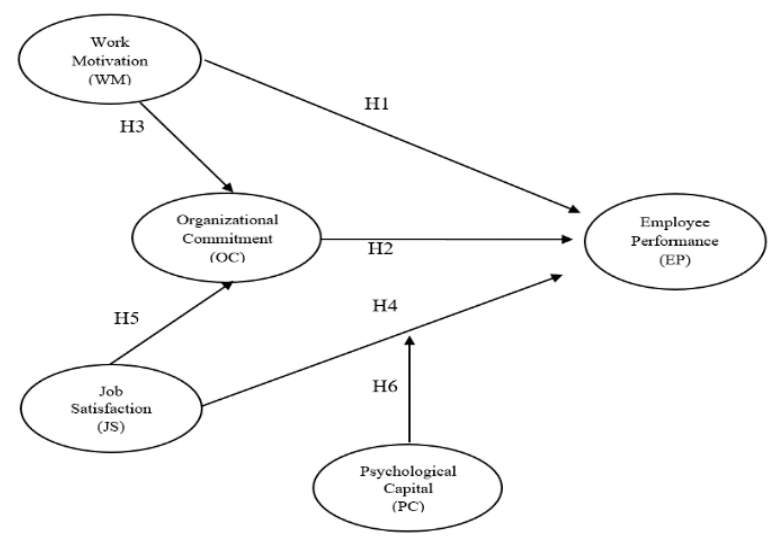

Figure 1. Hypotheses Model

Based on this research, we chose a research location in a government agency engaged in education, namely the Directorate of Senior High School, a unit of work at the Ministry of Education and Culture in Jakarta, Indonesia. The location was chosen as the object of research because the High School Directorate is one of the work units that implement the Corruption Free Zone Integrity Zone program, which embodies the bureaucratic program that the government has long launched. It means that employees have committed to work and contribute to producing the objective output of agencies by improving the performance of each. The population of this research is 110 employees of the Directorate of Senior High School with the status of state civil servants (ASN) using saturated sampling techniques/census, this is because all members of the population are used as samples (Sugiyo et al., 2018). Data collection using questionnaires distributed online to respondents using the Google Form application.

The variables used in this study include work motivation (WM), Organizational Commitment (OC), Job Satisfaction (JP), Employee Performance (EP), and Psychological Capital (PC). ). The Work Motivation (WM) variable uses an instrument developed by Anysari and Kasmir (2018), consisting of 34 statement items from 3 dimensions, namely need for achievement, need for affiliation, and need for power. The Organizational Commitment (OC) variable was measured using a questionnaire developed in Allen and Meyer's 1990 research, which included 24 statement items from 3 dimensions, namely Effective Commitment, Continue Commitment, and Normative Commitment. In measuring Job Satisfaction (JP), the instrument used for measurement uses instruments from Lee et al. (2017), which includes 34 statements consisting of 6 dimensions, namely; Salary and Welfare, Work Itself, Leader Behavior, Personal Growth, Interpersonal Relationship, and Job Competence. Employee 


\section{Windu Astuti Lia amalia}

Performance (EP) is measured through a questionnaire developed by (Pradhan and Jena, 2017), measured in 23 statement items, and consists of 3 dimensions: task performance, adaptive performance, and contextual performance. Meanwhile, the last variable, Psychological Capital (PC), the instrument used in the study, used Nafei. It consists of 24 statement items and four dimensions, including (1) self-efficacy, resilience, hope, and optimism. The assessment of the instrument of this study is by calculating the Likert scale (Brenneman, 2005), which centers on four alternative answers, including starting from the lowest level, namely STS (strongly disagree), then TS (disagree), S (agree), and levels. the last is strongly agree (SS).

Before the research, the instrument is distributed. First, a research instrument test is carried out to control, calibrate, and ensure that the instrument is valid. The value of validity and reliability can show whether a research instrument is good or bad (Hair et al., 2014). This becomes the basis for whether the instrument is feasible or not used by employees who work at the Directorate of Senior High School in Jakarta. The instrument was tested on 30 respondents outside of the actual research sample population. The validity and reliability test results on 135 statement items, which were declared valid and reliable, were 80 statements with a KMO or Kaiser-Meyer-Olkin value greater than 0.500 and a Cronbach's Alpha value> 0.600 (Appendix 3).

The research data analysis method is quantitative from the results of the questionnaire of respondents. It is tested by the Structural Equation Modeling (SEM) method or the Analysis of Moment Structures using the SmartPLS version 3 application. In addition to testing the validity and reliability of a model, SEM analysis also aims to test its suitability. Models in research using the Analysis of Moment Structures. SEM is also able to explain the complex relationship between variables and explain the direct/indirect effect between one / several variables with one / several other variables using confirmatory factor analysis / CFA (Hair et al., 2014)

\section{RESULTS AND DISCUSSION}

Based on the results of a study of 110 state civil servants who worked in government agencies of the Directorate of Senior High School in Jakarta in January 2021, it was shown that the male respondents were 57 people (51.8\%), with a working period of approximately 16 to 20 years. as many as 35 people (32.7\%), respondents with the most undergraduate education background (53.6\%), the most respondents were aged between 41 to 50 years, namely 44 people (40.0\%), and respondents with analyst positions. namely 33 people (30.0\%) (Appendix 4). Furthermore, the discussion of the results of data analysis begins with explaining the descriptive statistical analysis of the respondents and data analysis. The analysis carried out in this study includes several stages, including (1) by first evaluating or evaluating the 
measurement model (Outer model), evaluating the structural model (Inner Model), and testing the hypothesis. In data analysis techniques, the Smart Partial Least Square (SmartPLS) software is used because it is suitable in estimating (path model) or latent construct path analysis, which does not require large sampling (Sataloff et al., 2019).

According to Jogiyanto, a model measurement test is first carried out before testing the hypothesis to estimate indicators and latent variables (Sataloff et al., 2019). These tests including construct validity (including convergent validity and discriminant validity) and construct reliability tests. Convergent validity (convergent validity) looks at the loading factor and the average extracted variance (AVE). A measurement is called convergent validity if it meets the requirements for a loading factor value greater than 0.7 (loading factor $>0.7$ ) and an AVE greater than 0.5 (AVE> 0.5) (Sataloff et al., 2019). Meanwhile, to determine the discriminant validity, the method used is cross-loading on each variable, which can be said to have discriminant validity if it has a cross-loading value $\geq$ of 0.7 (Sataloff et al., 2019). The validity and reliability of the test can be done by designing an external model or measuring the model. A valid indicator value indicator has a loading factor greater than 0.5 (Original Sample value) and has a P-value (probability) smaller than 0.05 . The loading factor and $\dagger$ statistics of the first experimental results are based on SmartPLS output before eliminating the loading factor, which has a value less than 0.5. For the Work Motivation (WM) variable, it can be seen that nine items of statements are invalid. In the Job Satisfaction (JS) variable there are 10 statement items invalid. The Organizational Commitment $(\mathrm{OC})$ variable can be seen that there are eight invalid statement items. The Psychological Capital (PC) variable can be seen as eight invalid statement items. The Employee Performance (EP) variable shows that four items do not pass the validity test. Some items that do not pass the validity test are then eliminated until they are valid. Based on this, the model explanation is as follows:

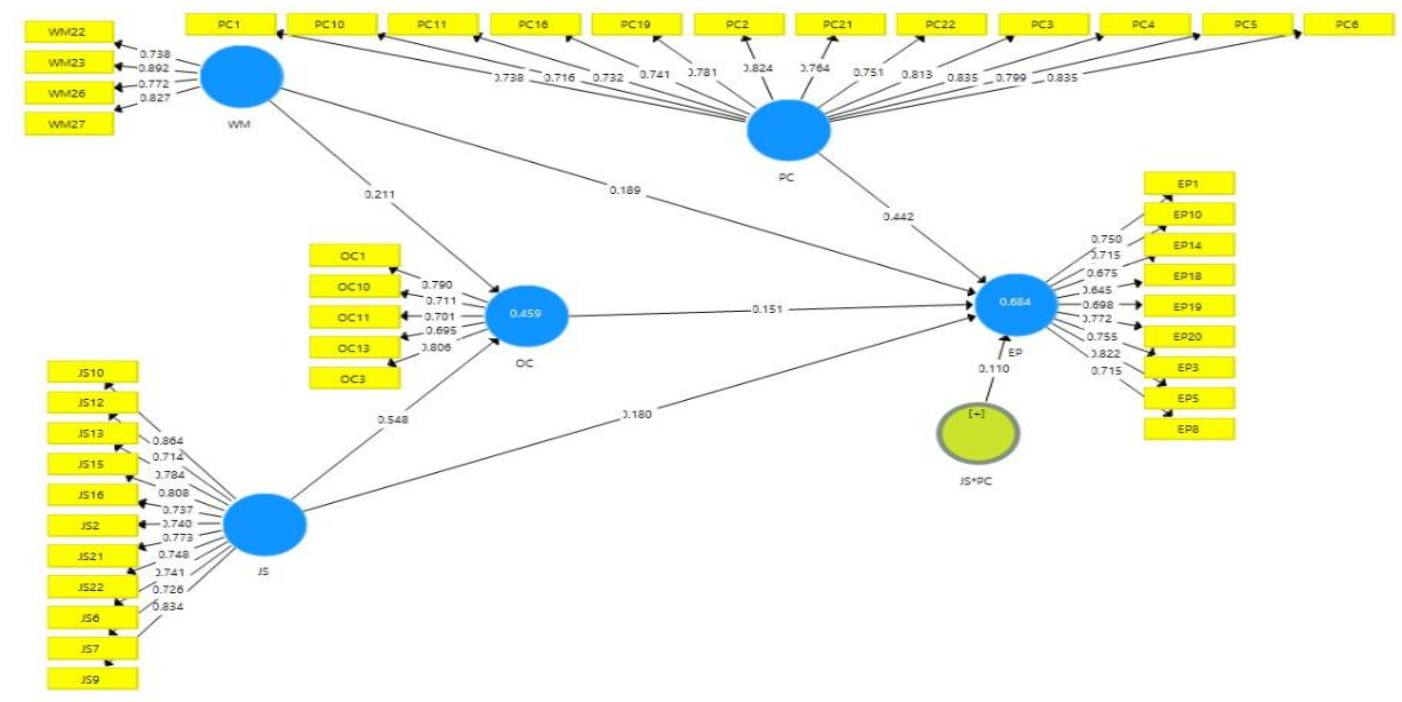

Figure 2. Model of Causal Relationships Between Variables 


\section{Windu Astuti Lia amalia}

The reliability testing results were carried out using internal consistency, where the reliability of the research instrument was tested using the Cronbach's Alpha method and composite reliability. Based on Hair et al. (2014), a construct can be categorized as good and reliable if its Cronbach alpha value and composite reliability are $\geq 0.6$. (Attachment 5). The composite reliability and Cronbach Alpha test results for the latent variables of Organizational Commitment, Work Motivation, Job Satisfaction, Psychological Capital, and Employee Performance above a value of 0.7. Meanwhile, the AVE value for each of the latent variables of Job Satisfaction, Work Motivation, Employee Performance, Organizational Commitment, Psychological Capital is above the value of 0.5 and has met the requirements for testing.

The discriminant validity test can be measured by comparing the score value of the crossloading factor. The value of the loading score on the intended construct must be greater than the loading value of other constructs (Appendix 5). The correlation coefficient for all indicators is greater than the value of the correlation coefficient for other indicators, such as the correlation between the Employee Performance (EP1) indicator and its construct Employee Performance (EP), which is 0.750 higher than the value for the construct of Job Satisfaction (JS) 0.533, with the value of the Organizational Commitment construct. (OC) 0.550, with the constructed value of Work Motivation (WM) of 0.553 and the constructed value of Psychological Capital (PC) 0.689. Based on the results of this analysis, a conclusion is conical that each indicator contained in the block is a construct with good discriminant validity.

To see the relationship between constructs, it is necessary to look at the research model's significant value and value (R-square).

Table. 1

Summary Results of R Square and Goodness of Fit Model

\begin{tabular}{|c|c|c|c|c|}
\hline Variable & R-Square & $\begin{array}{l}\text { R Square } \\
\text { Adjusted }\end{array}$ & Kategori & Q2 \\
\hline $\begin{array}{l}\text { EP } \\
\text { Work Motivation dan Job Satisfaction } \\
\rightarrow \text { Employee Performance }\end{array}$ & 0,459 & 0.669 & $\begin{array}{c}\text { Very } \\
\text { Strong }\end{array}$ & \multirow{2}{*}{$\begin{array}{l}=1-\left(1-\mathrm{R}^{2}\right)\left(1-\mathrm{R}^{2} 2\right) \\
=1-\left(1-0,684^{2}\right) \\
\left.0,459^{2}\right) \\
=1-(1- \\
=1-0,468)(0,210) \\
=0,902 \\
=90,2 \%\end{array}$} \\
\hline $\begin{array}{l}\text { OC } \\
\text { Work Motivation, Job Satisfaction dan } \\
\text { Organizational Commitment } \rightarrow \\
\text { Employee Performance }\end{array}$ & 0,684 & 0.448 & $\begin{array}{l}\text { Very } \\
\text { Strong }\end{array}$ & \\
\hline
\end{tabular}


The output of SmartPLS shows that the R square value of Organizational Commitment is 0.459 , meaning that the construct variables of Work Motivation and Job Satisfaction can explain the Organizational Commitment variable by $45.9 \%$. The R-square value of Employee Performance has a score of 0.684 which means that the Employee Performance construct variable can be explained by the variability of the Work Motivation, Job Satisfaction, and Organizational Commitment constructs of $68.4 \%$. In comparison, $31.6 \%$ is explained by other variables that are outside the model. The greater the value of the R-square, the greater the independent variable can explain the dependent variable, this indicates that the better the structural equation is. Apart from calculating the R-square value, the inner model measurement can also be seen using the Goodness of Fit Model method using predictive relevance (Q2). Based on the analysis results, the score of predictive relevance in this study was $90.2 \%$, which means that the model can explain the phenomenon under study. Based on these results, it can be concluded that the model has an excellent predictive value and can be used for hypothesis testing. To find out the goodness of the model, it is used by measuring $R$ Square as the absolute value of the individual contribution of each latent predictor variable to the R Square value of the latent variable. Effect sizes are grouped into three categories, namely weak (0.02), moderate (0.15), and strong (0.35) (Masydzulhak et al., 2016). The results of the $R$ Square output are as follows in table 1.

From the table, it is concluded that the contribution of the Work Motivation and Job Satisfaction variables to the Organizational Commitment and the contribution of the Work Motivation, Job Satisfaction, and Organizational Commitment variables to the category of Employee Performance is very strong.

Table. 3.1

Summary of Path Coefficients. Result of Inter-Variable Influence Test

\begin{tabular}{lccccc}
\hline & $\begin{array}{c}\text { Original } \\
\text { Sample (O) }\end{array}$ & $\begin{array}{c}\text { Sample } \\
\text { Mean (M) }\end{array}$ & $\begin{array}{c}\text { Standard } \\
\text { Deviation } \\
\text { (STDEV) }\end{array}$ & $\begin{array}{c}\text { T } \\
\text { Statistics } \\
\text { (O/STDEV) }\end{array}$ & P-Values \\
\hline JS -> EP & 0.180 & 0.183 & 0.089 & 2.013 & 0.045 \\
\hline JS -> OC & 0.548 & 0.556 & 0.074 & 7.415 & 0.000 \\
\hline JS*PC -> EP & 0.110 & 0.099 & 0.045 & 2.453 & 0.015 \\
\hline OC -> EP & 0.151 & 0.148 & 0.068 & 2.217 & 0.027 \\
\hline PC -> EP & 0.442 & 0.450 & 0.092 & 4.800 & 0.000 \\
\hline WM -> EP & 0.189 & 0.187 & 0.066 & 2.839 & 0.005 \\
\hline WM -> OC & 0.211 & 0.221 & 0.097 & 2.164 & 0.031 \\
\hline Data Sources for SmartPLS 2021 & & & &
\end{tabular}


Tabel. 3.2

Summary of Indirect Effect Result of Inter-Variable Influence Test

\begin{tabular}{|c|c|c|c|c|c|}
\hline & $\begin{array}{c}\text { Original } \\
\text { Sample (O) }\end{array}$ & $\begin{array}{r}\text { Sample } \\
\text { Mean (M) }\end{array}$ & $\begin{array}{l}\text { Standard } \\
\text { Deviation } \\
\text { (STDEV) }\end{array}$ & $\begin{array}{l}\text { T Statistics } \\
\text { (O/STDEV) }\end{array}$ & P-Values \\
\hline JS -> EP & 0.083 & 0.083 & 0.041 & 2.037 & 0.042 \\
\hline \multicolumn{6}{|l|}{ JS $->O C$} \\
\hline \multicolumn{6}{|l|}{$J S^{*} P C$-> EP } \\
\hline \multicolumn{6}{|l|}{$O C->E P$} \\
\hline \multicolumn{6}{|l|}{ PC -> EP } \\
\hline WM -> EP & 0.032 & 0.032 & 0.022 & 1.456 & 0.146 \\
\hline WM $->O C$ & & & & & \\
\hline
\end{tabular}

Table. 4

Hypothesis Research Test Results

\begin{tabular}{lccc}
\hline \multicolumn{1}{c}{ Hypothesis } & T Statistics & p values & Conclusion \\
\hline $\begin{array}{l}\text { H1: Work motivation affects } \\
\text { employee performance }\end{array}$ & $2,839>1,659)$ & $0,005<0,05$ & $\begin{array}{l}\text { Hypothesis } \\
\text { accepted }\end{array}$ \\
\hline $\begin{array}{l}\text { H2: Organizational commitment } \\
\text { affects employee performance }\end{array}$ & $2,217>1,659$ & $0,027<0,05$ & $\begin{array}{l}\text { Hypothesis } \\
\text { accepted }\end{array}$ \\
\hline $\begin{array}{l}\text { H3: Job satisfaction affects } \\
\text { employee performance }\end{array}$ & $2,013>1,659$ & $0,045<0,05$ & $\begin{array}{l}\text { Hypothesis } \\
\text { accepted }\end{array}$ \\
\hline $\begin{array}{l}\text { H4: Organizational commitment } \\
\text { mediates the relationship between }\end{array}$ & $1,456<1,659$ & $0,146>0,05$ & Hypothesis rejected \\
$\begin{array}{l}\text { work motivation and employee } \\
\text { performance }\end{array}$ & & $0,042<0,05$ & $\begin{array}{l}\text { Hypothesis } \\
\text { accepted }\end{array}$ \\
\hline $\begin{array}{l}\text { H5: Organizational commitment } \\
\text { mediates the relationship between } \\
\text { job satisfaction and employee } \\
\text { performance }\end{array}$ & $2,037>1,659$ & $0,015<0,05$ & $\begin{array}{l}\text { Hypothesis } \\
\text { accepted }\end{array}$ \\
$\begin{array}{l}\text { H6: Psychological Capital moderates } \\
\text { the relationship between job } \\
\text { satisfaction and employee } \\
\text { performance. }\end{array}$ & $2,453>1,659$ & 0,0 & \\
\hline
\end{tabular}

Source of SmartPLS 2021 Data

In making a decision, the hypothesis is accepted if the Path Coefficient output shows the value of t statistics $\geq \dagger$ table (1.659) and a significance value at P-value $<0.05$. Based on the table above for analysis 1, namely Work Motivation has a significant effect on Employee Performance, the hypothesis is accepted because the $t$ statistics value is $2.839>1.659$ or $\mathrm{P}$ values $0.005<0.05$. The second hypothesis is also accepted because the value of $\dagger$ statistics is 2.013> 1.659 or $P$ values $0.045<0.05$ ), which means a significant relationship between Job Satisfaction and Employee Performance. Analysis on hypothesis 3 is accepted, where Organizational Commitment has a significant effect on Employee Performance. This can be seen from the Path Coefficient output obtained by the t statistics value of 2.217> 1.659 or $\mathrm{P}$ values $0.027<0.05$. Whereas for the fourth hypothesis, the effect of Organizational Commitment mediation on the effect of Work Motivation on Employee Performance is not 
significant, because the results of the Indirect Effect output obtained by the value of $t$ statistics $1.456<1.659$ or $\mathrm{P}$ values $0.146>0.05$, so the hypothesis is rejected. For the 5 th analysis, the effect of Organizational Commitment mediation on the effect of Job Satisfaction on Employee Performance is significant because the Indirect Effect output obtained by $\dagger$ statistics is $2.037>1.659$ or $P$ values $0.042<0.05$, so the hypothesis is accepted. Furthermore, for the last hypothesis, the moderating effect of Psychological Capital on the effect of Job Satisfaction on Employee Performance is significant because it is seen from the Path Coefficient output that the t statistics value is $2.453>1.659$ or P-value $0.015<0.05$, so the hypothesis is accepted.

\section{Discussion}

This study intends to exploit the influence of job satisfaction, organizational commitment, and work motivation on employee performance mediated by organizational commitment and moderated by psychological capital. From the results of this study, it has been stated that Work Motivation affects Employee Performance. According to Jatmiko's (2015) research that explains that performance results from an employee's work output with the ability, experience, and length of work, employee performance is closely related to work motivation. Research from Loan (2020) explains that the work motivation variable positively influences employee performance variables, which means that the higher the employee work motivation variable in the organization, the higher the employee's performance. This is in line with the research of Suharto et al. (2019), which shows that work motivation variables have a positive effect on employee performance variables, and research by Suartina and Sadiartha (2019), which proves that there is a positive influence between work motivation and employee performance. Good employee motivation is due to encouragement from superiors, good working conditions, and good financial benefits. These results illustrate that the employees of the Directorate of Senior High School have good work motivation and impact employee performance. It is suspected that employees love the institution where they work and are satisfied with the awards given to them by the institution. The statistical tests also show that the Organizational Commitment variable has a positive influence on the Employee Performance variable. Organizational commitment is the relative strength employees have in identifying their involvement as part of the organization. Organizational commitment affects employee performance. According to research by Jabri and Ghazzawi, 2019 shows that organizational commitment can be used as a measuring tool to see some employee performance behaviors, discipline, and turnover. Employees who are involved in work will not want to leave the organization and become the basic capital to encourage high productivity. The effect of organizational commitment on performance has been proven based on the findings of a search conducted by Jaman et al. (2018), who stated that 


\section{Windu Astuti Lia amalia}

organizational commitment has a positive effect on improving performance. This means that good organizational commitment will encourage employees to work optimally.

Similarly, research by Rafiei et al. (2014) explains that affective commitment, ongoing commitment, and normative commitment have a positive effect on improving employee performance. The research results of Rahim and Jam'an (2018) state that organizational commitment affects employee performance, in line with Loan (2020), that organizational commitment positively affects employee performance. The better the Organizational Commitment in an organization given to its employees, the better the Employee Performance will be. In other words, when employees feel Organizational Commitment for all their work achievements, it will certainly make these employees have high performance and be beneficial for the organization's progress. This study shows that the employees of the SMA Directorate have a good commitment to the institution. Organizational commitment has been built for a long time to illustrate that the hearts and souls of employees have become one with the institution.

Based on the results of statistical tests, it is known that Job Satisfaction affects Employee Performance. The results of this study follow the research of Nimalathasan and Balasundaram (2011) and the research of Sadiq and Mohsin (2019) that job satisfaction positively influences employee performance. Platis et al. (2015) examined the relationship between job satisfaction and the nursing profession and found evidence that job satisfaction influences performance. They also found that the most important parameter of job satisfaction in health workers was that of managers. The results of research by Abdirahman et al. (2020) proves that job satisfaction has a positive relationship with employee performance, this explains that increasing employee job satisfaction standards will also increase employee performance. According to research conducted by Ismail (2016), the relationship between employee job satisfaction can improve employee performance. High school directorate employees have high satisfaction with what they receive from the institution. With high satisfaction, the employees will give all their abilities to improve the performance of the institution.

From the results of statistical testing, it can be seen that the output (original sample) positive influence between Work Motivation on Employee Performance is not mediated by the Organizational Commitment variable. This is also proven by Masydzulhak et al. (2016) that Organizational Commitment failed to mediate Work Motivation on Employee Performance because employees at PT Asian IzUsu Casting Center already have motivation from earning income in the form of salaries and incentives provided, without any influence from organizational commitments owned by their employees. They will be motivated if the company cares and rewards them for the work they produce. The company gives the 
greater the salary and bonuses, the greater the performance that will be generated. In line with the results of this study, employees who work in the SMA Directorate, even though they have high work motivation, if mediated by organizational commitment does not affect their performance, so even without mediation by organizational commitment, performance will still increase. This is because employees of the High School Directorate have high motivation. After all, the income received and salary and food allowance every month, employees also get a relatively high-performance allowance. Without the influence of organizational commitment, the performance produced by employees is relatively high.

However, it is different from Suartina and Sadiartha's (2019) research, which proves that work motivation significantly influences employee performance, and organizational commitment can mediate between the two. Likewise, Rahim and Jam'an (2018) research concludes that if the motivation variable has a significant effect on employee performance variables through organizational commitment variables, the better an employee's organizational commitment will increase work motivation/motivation, thereby increasing employee performance. This finding is unique considering that this study proves that work motivation affects Organizational Commitment. This is possible considering that Organizational Commitment cannot mediate the effect of Work Motivation on Employee Performance. Work Motivation has a positive effect on Employee Performance without the need to be mediated by other variables, in this case, the Organizational Commitment variable. This is at the same time to strengthen the theory from the results of research conducted by Stoyanov (2017), that work motivation is an impulse that encourages a person to carry out an activity and an inner urge to do a job in achieving the desired goal.

The results of statistical testing show that the output (original sample) of the effect of Job Satisfaction on Employee Performance is mediated by the Organizational Commitment variable, which shows that there is a positive influence on the Organizational Commitment variable, which mediates the effect of Job Satisfaction on Employee Performance. This follows Ismail's (2016) research, which proves organizational commitment has a relationship with employee performance. Employees who are satisfied with their work and have a high commitment to the organization will improve an employee's performance. Following research conducted by Wagiman and Sutanto (2019) proves that organizational commitment is influenced by job satisfaction and employee performance variables. Job satisfaction also affects organizational commitment, this is evidenced by Meria and Amalia (2018), which states that there is a significant influence on the relationship between Job Satisfaction and Employee Performance variables mediated by Organizational Commitment. If the Job Satisfaction felt by employees is stable and increasing, it will have an 


\section{Windu Astuti Lia amalia}

impact on increasing Employee Performance. For Organizational Commitment, it turns out that after being tested, it can moderate the effect of Job Satisfaction on Employee Performance. High school directorate employees have high satisfaction with what they receive from the institution. With this high satisfaction, organizational commitment is formed which then has an impact on improving performance. Building organizational commitment cannot be obtained in a short time. Employee organizational commitment will grow slowly when employees have adequate job satisfaction.

Based on the results of statistical testing, it can be seen that the output (original sample) of the effect of Job Satisfaction on Employee Performance is moderated by the Psychological Capital variable, which shows a positive relationship. This is in line with research by Nafei (2015), which proves that Psychological Capital can influence employee performance by developing self-efficiency, optimism, hope, and resilience/resilience in employees. Rabenu et al. (2017) stated that if someone's Psychological Capital can be appropriately managed, it will positively affect their performance. Santos et al. (2018) expressed their opinion that an employee will need good psychological capital to do his job optimally to produce maximum performance in carrying out his duties. High school directorate employees have high satisfaction with what they expect from the institution for the life of themselves and their families. This high job satisfaction affects improving employee performance. Variable Psychological Capital will have a strong influence on employee job satisfaction on employee performance. With a good psychological mental condition employees can increase the effect of job satisfaction on employee performance.

\section{CONCLUSION}

Based on the results of this study concluded that Work Motivation, Job Satisfaction, and Organizational Commitment directly affect Employee Performance. Organizational Commitment cannot mediate the relationship between Work Motivation and Employee Performance, but Organizational Commitment can mediate the relationship between Job Satisfaction and Employee Performance. The organization has long been formed. For the last hypothesis, Psychological Capital can moderate the relationship between Job Satisfaction and Employee Performance. This provides a new view that the model compiled in this study can be used as a basis for predicting the effect of the relationship between Work Motivation and Job Satisfaction with Employee Performance mediated by the Organizational Commitment variable. The model being tested also involves the Psychological Capital variable, which acts as a moderating variable for the effect of Job Satisfaction on Employee Performance. Thus the results of this study can be a reference for further research in identifying other factors that affect the Employee Performance variable outside the Work Motivation and Job Satisfaction variables and also the Organizational Commitment variable 
as a mediating variable and the Psychological Capital variable, which acts as a moderating variable to create a better new model.

The implication of this research is expected to be helpful for the Directorate of Senior High School, especially for the Administration Subdivision, which can be used as an illustration of how the human resources that are owned by each employee who works with Work Motivation, Organizational Commitment, Job Satisfaction, and Psychological Capacity will affect Employees Performance. In this study, Work Motivation directly affects Employee Performance without having to be mediated by the Organizational Commitment owned by the employee. Therefore organizations must pay attention to and implement Work Motivation properly. It is intended that through good Work Motivation, it is hoped to achieve a higher level of Employee Performance. Motivating the company following the needs of employees will foster employee commitment to the company to produce an optimal performance for the company (Rahim and Jam'an, 2018).

This study's limitation is that future studies can expand the model to predict the effect of certain variables on Employee Performance variables. The addition of variables that can affect Employee Performance is possible because it is seen from the calculation of the Rsquare value where there are still potential variables outside the model that affect Employee Performance. Another variable as a mediator/moderator might increase the relationship between work motivation and employee performance to replace the organizational commitment variable that did not have a significant effect in this study.

\section{REFERENCES}

Abdirahman, H.I.H., Najeemdeen, I.S., Abidemi, B.T. and Ahmad, R. 2020. The Relationship between Job Satisfaction, Work-Life Balance and Organizational Commitment on Employee Performance. Advances in Business Research International Journal, 4(1): 42.

Allen and Meyer, 1990, n.d. Organizational+Commitment-Allen-Meyer+(1990).pdf.

Amalia, L. 2018. Model Motivasi Kerja Dan Komitmen Organisasional Sebagai Konsekuensi Dari Keterlibatan Kerja Karyawan Non Dosen Pts Di Dki Jakarta. Forum Ilmiah Volume 15 Nomor 1, 15: 30.

Andyanto, D.J., Pratikto, H. and Jaman, I.W. 2018. The Effect of Organizational Commitment and Organizational Culture on Employee Performance through Employee Satisfaction (Study of Gondanglegi Islamic Hospital of Malang). European Journal of Business and Management, 10(8): 10. 
Avey, Reichard, Luthans, M. 2011 . Meta-Analysis of the Impact of Positive Psychological Capital on Employee Attitudes, Behaviors, and Performance. Computational Complexity, 2(1): 1-9.

Aziri, B. 201 1. Job Satisfaction, a Literature Review. Management research and practice, 3(1): 77-90.

Brenneman, W.A. 2005. Statistics for Research. Technometrics, 47(1):100-100.

Darman, 2015. TEORI-TEORI MANAJEMEN DAN ORGANISASI.

Eka, S., Ariva, V. and Fauzana, F., 2018. Jurnal Manajemen Indonesia Analisis Faktor Kondisi Ekonomi , Tingkat Pendidikan dan Kemampuan Berwirausaha Terhadap Kinerja Usaha Bagi Pengusaha Pindang di Desa Cukanggenteng. Jurnal Manajemen Indonesia, 18(3), pp.197-208.

Hair, Joseph F. , Black, Jr, William C. Babin, Barry J. and Anderson, R.E. 2014. Pearson Multivariate Data Analysis, 7/E - Joseph F. Hair, Jr, William C. Black, Barry J. Babin and Rolph E. Anderson. Pearson New International Edition, 30: 816.

Hair, J.F., Black, W.C., Babin, B.J. and Anderson, R.E. 2014. Pearson New International Edition: Multivariat Data Analysis. Exploratory Data Analysis in Business and Economics.

Hashish, E.A.A. 2015. Relationship between ethical work climate and nurses ' perception of organizational support, commitment, job satisfaction and turnover intent. Nursing Ethics, 16: 1-16.

Hsu, Y., Chun-yang, P., Pi-hui, T. and Ching-wei, T. 2019. Managerial Coaching, Job Performance, and Team Commitment: The Meditating Effect of Psychological Capital. Advances in Management and Applied Economics, 9(5): 101-125.

IsmailL, A.R.A.R. 2016. Effect Of Job Satisfaction On Organizational Commitment. 26 ManagementandMarketing, volume XIV, issue 1/2016, 2714(1): 26-40.

Jabri, B. Al and Ghazzawi, I. 2019. Organizational Commitment: A Review of the Conceptual and Empirical Literature and a Research Agenda. International Leadership Journal, 11 (March): 78-119.

Jatmiko, E. 2015. Pengaruh Motivasi Kerja Dan Komitmen Organisasional Terhadap Kinerja Karyawan (Studi Pada Karyawan Kompartemen Pabrik. Jurnal Administrasi Bisnis S1 Universitas Brawijaya, 21 (1): 85755. 
Kalkavan, S. and Katrinli, A. 2014. The Effects of Managerial Coaching Behaviors on the Employees' Perception of Job Satisfaction, Organisational Commitment, and Job Performance: Case Study on Insurance Industry in Turkey. Procedia - Social and Behavioral Sciences, 150: 1137-1147.

Kasmir, D.A.and, 2018. Pengaruh Motivasi Kerja Mcclelland, Kepemimpinan Transformasional Dan Lingkungan Kerja Non Fisikterhadap Kinerja Aparatur Sipil Negara Pada Direktorat Jenderal Ketahanan Dan Pengembangan Akses Industri Internasional. VIII(2): 263-274.

Lee, X., Yang, B. and Li, W. 2017. The influence factors of job satisfaction and its relationship with turnover intention: Taking early-career employees as an example. Anales de Psicologia, 33(3): 697-707.

Loan, L.T.M. 2020. The influence of organizational commitment on employees' job performance: The mediating role of job satisfaction. Management Science Letters, 10(14): 3307-3312.

Luthans, 2015. Organizational Behavior. Twelfth Ed ed. Hospital Administration. Paul Ducham.

Luthans, F., Avey, J.B., Avolio, B.J. and Peterson, S.J. 2010. The development and resulting performance impact of positive psychological capital. Human Resource Development Quarterly, 21(1): 41-67.

Luthans, F., Avolio, B.J., Avey, J.B. and Norman, S.M. 2007. Positive psychological capital: Measurement and relationship with performance and satisfaction. Personnel Psychology, 60(3): $541-572$.

Masydzulhak, P.D., Ali, P.D.H. and Anggraeni, L.D. 2016. The Influence of work Motivationand Job Satisfaction on Employee Performance and Organizational Commitment Satisfaction as an Intervening Variable in PT. Asian Isuzu Casting Center. Journal of Research in Business and Management, 4(10): 1-10.

Mcclelland, D.C. and Boyatzis, R.E. 2016. The Wiley Encyclopedia of Personality and Individual Differences Volume IV: Clinical, Applied and Cross -Cultural Research. IV.

Meria, L. 2018. Pengaruh Konflik Pekerjaan Keluarga dan Kepuasan Kerja Terhadap Komitmen Organisasional. Jurnal Ekonomi, 9(2): 204-212.

Mohammed Inuwa, 2016. Job Satisfaction and Employee Performance of Greek Banking Staff: An Empirical Investigation. Acta Universitatis Lodziensis. Folia Oeconomica, Acta Unive(December). 
Muda, I., Rafiki, A. and Harahap, M.R. 2014. Factors Influencing Employees ' Performance : A Study on the Islamic Banks in Islamic Science University of Malaysia University of North Sumatera. International Journal of Business and Social Sience, 5(2): 73-81.

Muhammad Fauzi1), Moch Mukeri Warso2), А.Т.H. and Котова, Т.Н. 2016. Pengaruh Budaya Organisasi Dan Kepuasan Kerja Terhadap Kinerja Karyawan Dengan Komitmen Organisasi Sebagai Variabel Intervening (Studi Pada Karyawan PT. Toys Games Indonesia Semarang). Journal of Management Vol.02 No.02, Maret 2016, 9(1): 82-94.

Nafei, W. 2015. The Effects of Psychological Capital on Employee Attitudes and Employee Performance: A Study on Teaching Hospitals in Egypt. International Journal of Business and Management, 10(3).

Nimalathasan, Balasundaram, 2011, 2011. The Impact of Job Satisfaction on Employees' Performance: A Case Study of Al Hayat Company - Pepsi Employees in Erbil, Kurdistan Region - Iraq Sabir. International Journal of Humanities and Social Science, 2(14).

Platis, C., Reklitis, P. and Zimeras, S. 2015. Relation between Job Satisfaction and Job Performance in Healthcare Services. Procedia - Social and Behavioral Sciences, 175: 480-487.

Pradhan, R.K. and Jena, L.K. 2017. Employee Performance at Workplace: Conceptual Model and Empirical Validation. Business Perspectives and Research, 5(1): 69-85.

Puspitawati and Riana, 2014. Pengaruh Kepuasan Kerja Terhadap Komitmen Organisasional Dan Kualitas Layanan. Jurnal Manajemen, Strategi Bisnis dan Kewirausahaan, 8(1): 6880.

Rabenu, E., Yaniv, E. and Elizur, D. 2017. The Relationship between Psychological Capital, Coping with Stress, Well-Being, and Performance. Current Psychology, 36(4): 875-887.

Rafiei, M., Taghi Amini, M. and Foroozandeh, N. 2014. Studying the impact of the organizational commitment on the job performance. Management Science Letters, 4(8): 1841-1848.

Rahim, A.R. and Jam'an, A. 2018. The analysis of influence of motivation and organizational commitment on employees' performance in Telkom Kandatel Gorontalo Province. Problems and Perspectives in Management, 16(4): 429-443.

Rahman, Bachri, F. 2013. pengaruh komitmen organisasional, motivasi intrinsik dan motivasi ekstrinsik terhadap kinerja dokter(Studi pada Dokter Rumah Sakit Umum Dae rah Ulin 
Banjarmasin ). Jurnal Wawasan Manajemen, 1 (3): 299-321.

Saari, L.M. and Judge, T.A. 2004. Employee attitudes and job satisfaction. Human Resource Management, .

Sabir SAdiq and Zrar Mohsin, 2019, 2019. The Impact of Job Satisfaction on Employees' Performance: A Case Study of Al Hayat Company - Pepsi Employees in Erbil, Kurdistan Region - Iraq: 163-176.

Sadiartha, A.A.N.G. and Suartina, I.W. 2019. the Effect of Work Motivation on the Employee Performance With Organizational Commitments As Moderation Variables At Pt. Asuransi Jiwasraya, Denpasar. Journal of Life Economics, 6(3): 249-264.

Santos, A.S., Reis Neto, M.T. and Verwaal, E. 2018. Does cultural capital matter for individual job performance? A large-scale survey of the impact of cultural, social and psychological capital on individual performance in Brazil. International Journal of Productivity and Performance Management, 67(8): 1352-1370.

Santos, N.and V. and 2018, 2015. Does cultural capital matter for individual job performance? A large-scale survey of the impact of cultural, social and psychological capital on individual job performance in Brazil. The Eletronic Library, 34(1): 1-5.

Sataloff, R.T., Johns, M.M. and Kost, K.M. 2019. STRUCTURAL EQUATION MODELING (SEM) BERBASIS VARIAN: Konsep Dasar dan Aplikasi dengan Program SmartPLS 3.2.8 dalam Riset Bisnis. 1st, Juni 20 ed. DKI Jakarta.

Seligman, M.E. and Csikszentmihalyi, M. 2000. Positive psychology. An introduction. The American psychologist, 55(1): 5-14.

Setar, S.B., Buitendach, J.H. and Kanengoni, H. 2015. The moderating role of psychological capital in the relationship between job stress and the outcomes of incivility and job involvement amongst call centre employees. SA Journal of Industrial Psychology, 41 (1): $1-13$.

Stoyanov, S. 2017. A theory of human motivation. A Theory of Human Motivation, (13): 1-87.

Suharto, Suyanto and Hendri, N. 2019. The impact of organizational commitment on job performance. International Journal of Economics and Business Administration, 7(2): 189206.

Viswesvaran, C. and Ones, D.S. 2000. Perspectives on Models of Job Performance. International Journal of Selection and Assessment, 8(4): 216-226. 
Windu Astuti

Lia amalia

Wagiman, S. and Sutanto, H.A. 2019. Job Satisfaction Mediates Relationship Between

Organizational Commitments and. Daya Saing Jurnal EKonomi Manajemen Sumber Daya, 21 (2): 132-143.

Yusuf, N. and Metiboba, S. 2018. Work Environment and Job Attitude among Employees in a Nigerian Work Organization. Journal of Sustainable Society, 1 (2): 36-43. 


\section{APPENDIX -3}

\section{SURVEY QUESTIONNAIRE}

1. I have an extraordinary job target

2. I always do all the work that is my responsibility.

3. I will try to improve my work performance

4. I like to do the job perfectly

5. I used to be a place to confide in for my friends

6. I like to visit to strengthen the relationship with my family and friends

7. I love eating with my friends

8. I don't like to stand out from other people

9. I like it when other people care about me

10. I love recruiting new employees to work on the team that I lead

11. I need to get a strategic position that many people covet

12. I like to influence other people

13. I am willing to work hard to get a higher promotion

14. I like to live my job until I retire

15. I have an emotional bond with the office where I work

16. I can easily forget emotional ties with my old office to like my new office more (-)

17. I have no emotional ties with my office (-)

18. It will be very difficult for me to leave my office

19. There are too many risks that I will face if I quit my current job

20. I will think long if I have to leave my current job

21. I have no other job options if I have to quit my current job

22. If I leave the office where I work now, there will be too many consequences

23. I don't like changing offices/jobs (-)

24. I will not leave my job even though there are better job offers

25. I will be loyal to the office where I work

26. I feel there is no difference in the treatment of female or male employees in my office 
27. I feel satisfied with the well-being that the office is giving me right now.

28. I feel that my work has been well rewarded.

29. The welfare in my office can be done fairly

30. I feel satisfied with the opportunity to get more income

31. I feel satisfied with the work that I am currently doing.

32. I feel like I have fun with my current job.

33. I am happy with my current job.

34. My job provides a stable income for my life.

35. My boss is good at doing his job.

36. I like my boss because he can help me to get the job done.

37. My boss is fair to all of his subordinates

38. I feel satisfied with my job promotion opportunity.

39. I always gain knowledge from the work I do.

40. I am willing to accept a difficult job.

41. I feel happy to be able to work with my colleagues.

42. I feel satisfied with the way colleagues relate well to each other at the company.

43. Due to the limited capacity of employees in the office, I have to work hard at my job. (-)

44. The role I play in the team has had a positive impact on my co-workers.

45. When doing a good job, I take time to communicate with my co-workers.

46. Due to work pressure, it made me unable to do what I wanted.

47. Performance procedures in my office, make me tired at work.

48. I was able to complete a job that was better than the standard set

49. I can complete every job scrupulously without supervision

50. I am very passionate about work

51. I can complete the work that is my responsibility within the stipulated time.

52. I am adept at dealing with organizational change

53. Mutual understanding in the team is important to me

54. I don't like being criticized by my work team (-) 
55. I am used to assisting my co-workers, when needed

56. I like to have big responsibilities

57. I like to praise my colleagues' work for their work achievements

58. I feel satisfied if I succeed in coaching my co-workers

59. I like to share knowledge with my colleagues

60. I am used to giving directions to other people outside of my main duties and functions

61. I am confident in analyzing future problems to find solutions

62. I am confident in representing inter-sectoral meetings in my agency

63. I am confident to contribute to the discussion meeting

64. I am confident in setting targets for my work

65. I am confident to be the liaison between work units

66. I am confident that I can present the work program to my stakeholders/colleagues

67. I am capable of solving complex problems

68. I am very passionate about work

69. I think all problems have solutions

70. I feel quite successful at work

71. I have a lot of creativity at work

72. I have a purpose in life that I have set

73. I am used to dealing with work pressure calmly

74. I've been tested in the face of adversity

75. I am used to handling a lot of work

76. In the face of uncertain situations, I remain optimistic about getting the best

77. I can predict a success or failure at work

78. I always think positively about my work

79. I am optimistic about my work

80. I feel optimistic about the career path at my job 
Windu Astuti

Lia amalia

APPENDIX - 4

\begin{tabular}{|c|c|c|c|}
\hline Characteristics & Profile & $\begin{array}{l}\text { Number of } \\
\text { Respondents }\end{array}$ & Percentage \\
\hline \multirow{3}{*}{ Gender } & Male & 57 & $51.82 \%$ \\
\hline & Female & 53 & $48.18 \%$ \\
\hline & Amount & 110 & $100 \%$ \\
\hline \multirow{6}{*}{ Work Period } & Less than 5 years & 5 & $4.55 \%$ \\
\hline & $5-10$ years & 12 & $10.91 \%$ \\
\hline & $11-15$ years old & 31 & $28.18 \%$ \\
\hline & $16-20$ years & 36 & $32.73 \%$ \\
\hline & more than 20 years & 26 & $23.64 \%$ \\
\hline & amount & 110 & $100 \%$ \\
\hline \multirow{7}{*}{$\begin{array}{l}\text { educational } \\
\text { background }\end{array}$} & Junior High School & 0 & $0.00 \%$ \\
\hline & Senior High School / Diploma 1 & 18 & $16.36 \%$ \\
\hline & Diploma 3 & 4 & $3.64 \%$ \\
\hline & Bachelor Degree & 59 & $53.64 \%$ \\
\hline & Master Degree & 26 & $23.64 \%$ \\
\hline & Doctorol Degree & 3 & $2.73 \%$ \\
\hline & amount & 110 & $100.00 \%$ \\
\hline \multirow{6}{*}{ Age } & Less than 25 years old & 2 & $1.82 \%$ \\
\hline & $25-30$ years & 4 & $3.64 \%$ \\
\hline & 31 - 40 years & 28 & $25.45 \%$ \\
\hline & $41-50$ years & 44 & $40.00 \%$ \\
\hline & more than 50 years & 32 & $29.09 \%$ \\
\hline & amount & 110 & $100.00 \%$ \\
\hline \multirow{5}{*}{ Job Title } & Functional & 14 & 34.24 \\
\hline & Analyst & 33 & 24.58 \\
\hline & Manager & 32 & 27.97 \\
\hline & Administration & 31 & 13.22 \\
\hline & amount & 110 & $100 \%$ \\
\hline
\end{tabular}

